\title{
Cultivos celulares como alternativa para el aislamiento y la producción de biológicos contra el Virus de Influenza
}

\author{
Luisa Fernanda Mancipe J, MV', Gloria Ramírez N, Ph.D', \\ Jairo Jaime C, Ph.D', Victor Vera A., Ph.D'
}

1. Línea de Investigación en Microbiología y Epidemiología. Facultad de Medicina Veterinaria y de Zootecnia. Universidad Nacional de Colombia, Sede Bogotá.

Correspondencia: gcramirezn@unal.edu.co

Recibido: 06/09/2011 - Aceptado: 24/10/2011

\section{Resumen}

El virus de influenza ha sido reconocido como un importante patógeno en poblaciones humanas y animales, ya que es el principal causante de enfermedades respiratorias. Muchas vacunas y aislamientos de virus de influenza humana y animal son realizadas actualmente en huevos embrionados, siendo este el método usado tradicionalmente por décadas. Sin embargo, se han encontrado inconvenientes en la elaboración de vacunas ya que el proceso de fabricación es de capacidad limitada (se requiere aproximadamente un huevo para generar una dosis vacunal) y alta demanda tiempo, disminuyendo su habilidad para generar biológicos rápidamente en el caso de una pandemia. El empleo de líneas celulares continuas para la producción de vacunas virales nace como alternativa que ofrece diversas ventajas: (i) oportunidad de emplear células completamente caracterizadas y estandarizadas, (ii) producción y planeación permanente de vacunas y (iii) los biológicos pueden ser producidos de forma más rápida.

El objetivo de esta revisión es analizar las diferentes alternativas empleadas en el cultivo y/o aislamiento de virus de influenza, enfatizando en el uso de cultivos celulares como sustrato para el aislamiento y la producción de biológicos destinados a la salud humana y animal.

Palabras clave: cultivos celulares, huevos embrionados, aislamiento, vacunas, virus de influenza.

\section{Abstract \\ Cell culture as an alternative for isolation and production of biologics against influenza virus}

Influenza Virus has been recognized as an important pathogen in human and animal populations causing many respiratory diseases. Vaccine production and isolation of human and animal influenza viruses are made mainly in chicken embryo eggs, being the conventional method used for decades, however, several issues have been found for vaccine manufacture related with low efficiency of processes due to limited capacity of production (sometimes requiring one or two eggs to obtain a vaccine dose) and time spending that leads to decrease in the ability for fast vaccine production processes in a pandemic situation. The use of continuous cell lines for viral vaccine manufacture rises as a feasible choice offering several advantages including the opportunity to use fully characterized and standardized cells; in addition, cell-culture-derived vaccines don't require further planning and vaccines can be produced rapidly. 
The aim of this paper is to know different alternatives employed in culture and isolation of influenza viruses, emphasizing in the use of cell culture as a substrate for isolation and manufacture of vaccines for use in humans and animals.

Key words: cell cultures, chicken embryo eggs, isolation, vaccines, influenza virus.

\section{Introducción}

La influenza es una enfermedad infecciosa cuya distribución y rango de huéspedes es muy amplio. Es causada por un virus de tipo RNA perteneciente a la familia Orthomyxoviridae, en la cual además de los géneros Influenzavirus $\mathrm{A}, \mathrm{B}$ y C (afectan animales vertebrados), se encuentran los Isavirus (afectan al salmón) y Thogotovirus (afectan mosquitos) (1).

Los virus de influenza tipo A se caracterizan por ser envueltos y pleomórficos. Su genoma está constituido por RNA de polaridad negativa dividido en 8 segmentos que codifican para al menos once proteínas (2). Los segmentos 1, 2 y 3, codifican para el complejo polimerasa del virus, compuesto por 2 polimerasas básicas (PB1 y PB2) y una polimerasa ácida (PA); los segmentos 4 y 6 codifican para las glicoproteínas de superficie hemaglutinina y neuraminidasa (HA y NA, respectivamente) las cuales constituyen los mayores antígenos virales; el segmento 5 codifica para la nucleoproteína (NP), la cual forma un complejo con el RNA viral. El segmento 7 codifica para dos proteínas las cuales comparten una región corta: la proteína de matriz M1 que le da estructura a la cápside viral y la proteína de matriz M2 que funciona como un canal de intercambio iónico. Finalmente, el segmento 8 codifica para las proteínas NS1 (proteína no estructural) y NEP (NS2) que manejan el transporte, transcripción y ensamble del RNA viral $(1,3)$.

Los virus de influenza del género $A$ infectan una variedad de especies, incluyendo humanos, cerdos, caballos, mamíferos marinos y varias especies de aves. Estos virus se clasifican en subtipos basados en diferencias antigénicas entre sus dos glicoproteínas de superficie (HA y NA). Hasta la fecha se han identificado 16 subtipos de HA (H1-H16) y 9 subtipos de NA (N1-N9) $(1,3)$.

El virus de Influenza es el ejemplo clásico de un virus genéticamente inestable, lo cual se relaciona básicamente con dos mecanismos que le permiten modificar su constitución antigénica. El drift antigénico (acumulación gradual de pequeñas mutaciones en los genes que codifican para la HA y/o la NA) confieren al virus la capacidad de evadir el sistema inmune del hospedero ya que dichos cambios pueden interferir con el reconocimiento apropiado por parte de anticuerpos generados por infecciones previas, favoreciendo de esta forma la diseminación del virus $(3,4)$. Un cambio más drástico denominado shift antigénico, que consiste en el intercambio de segmentos completos de HA y/o NA entre dos subtipos diferentes de influenza que simultáneamente infectaron la misma célula, pueden dar origen a un nuevo virus que no había circulado antes en la población humana y/o animal representando un riesgo potencial de infección con graves consecuencias en términos de morbilidad y mortalidad $(5,6)$. Cambios antigénicos de este o cualquier tipo, cumplen un papel determinante en el diseño de vacunas para el control de influenza, generando la búsqueda de diferentes sustratos y ambientes que sean capaces de replicar eficientemente el virus para la elaboración de biológicos de manera rápida y eficiente (7).

El desarrollo de biológicos contra influenza data de hace más de 60 años, cuando se prepararon vacunas inactivadas empleando como sustrato huevos embrionados de pollo (8). Aunque este método ha perdurado en el tiempo, presenta limitantes tales como una baja eficiencia y restricción en la disponibilidad de cantidades apropiadas del biológico en un momento dado, ya que se requiere realizar una planeación previa de 6 a 12 meses para asegurar que millones de huevos fértiles de alta calidad estén disponibles para su producción. Otra limitante de dicho sustrato es que al realizar pasajes del virus en los huevos embrionados se puede alterar la estructura de la hemaglutinina (HA) generando un virus diferente a la cepa original, la respuesta inmune a la HA alterada no va a corresponder exactamente al 
virus circulante reduciendo la eficiencia de la vacuna contra influenza (9).

Con el fin de superar los inconvenientes mencionados anteriormente, se ha evaluado el empleo de líneas celulares continuas para la producción de vacunas contra influenza. Ventajas tales como la disponibilidad de líneas celulares estandarizadas y caracterizadas que permiten una planeación y producción permanente como sustrato para la utilización en la fabricación de vacunas, nace como opción para la generación eficaz y eficiente de biológicos contra influenza (8).

El propósito de esta revisión es hacer un recorrido a través del tiempo de las diferentes alternativas empleadas en el cultivo y/o aislamiento de virus de influenza, así como llevar a cabo un análisis crítico de la información disponible en relación con el uso de los cultivos celulares como substrato para el aislamiento y la producción de biológicos destinados principalmente a su uso en humanos y animales.

\section{Replicación del virus de Influenza In vivo e In vitro}

El proceso inicial de infección por virus de influenza es activado por la interacción entre la hemaglutinina viral y los receptores relacionados con residuos de ácido siálico (SA) presentes en las glicoproteínas de las células (10). Los receptores celulares de ácido siálico presentan una conformación particular: los residuos de $S A$ están unidos al penúltimo grupo carbohidrato por enlaces del tipo $\alpha-2.3, \alpha-2.6$ o $\alpha-2.8$ y muchas cepas de virus de influenza A se caracterizan por emplear los tipos $\alpha-2.3$ y $\alpha-2.6$ como receptor primario. In vivo, en humanos los virus de influenza se unen preferencialmente a enlaces de tipo SAa-2.6 presentes en el tracto respiratorio superior, mientras los virus de influenza aviar se unen a receptores SA $\alpha$ 2.3 predominantes en el tracto digestivo de las aves $(11,12)$. Por lo anterior la distribución de ambos tipos de receptores, $S A \alpha-2.3$ y $S A \alpha-2.6$, en el epitelio traqueal del cerdo (13), soporta la hipótesis de que esta especie actúa como un mezclador potencial de virus de influenza de origen humano y aviar.

Los virus de influenza A presentan propiedades de crecimiento In vitro, que dependen de la cepa y la preferencia de ésta por el receptor celular que esté presente en la célula blanco (14). Además la replicación de los virus de influenza en la célula huésped depende de factores celulares como la activación de las proteasas que clivan la $\mathrm{HA}$ inactiva (HA0) en HA1 y HA2, haciendo el virus infeccioso para las células susceptibles (15).

Las cepas del virus de influenza aisladas en líneas celulares se comportan de una manera similar en cuanto a su preferencia por unirse a ciertos receptores, es así como virus provenientes de mamíferos se unen a enlaces de ácido siálico en la penúltima galactosa en la posición $\alpha-2.6(\mathrm{SA} \alpha-2.6 \mathrm{Gal})$ predominantes en la superficie de células respiratorias del tracto superior $(16,17)$, mientras que los virus producidos en huevos embrionados se unen a los receptores que contienen SA a-2.3 Gal típicos para especies aviares, debido a que las células epiteliales de la cavidad alantoica posee únicamente receptores de este tipo $(8,18,19)$.

Por lo tanto, dentro de los aspectos a considerar para la elección del sustrato celular a emplear para cultivar un virus de influenza en particular, es indispensable garantizar que el sustrato empleado posea células con características y receptores apropiados que favorezcan la replicación viral.

\section{Huevos embrionados Vs. cultivos celulares}

En la búsqueda de alternativas diferentes para el aislamiento y/o crecimiento de virus de influenza, la utilización de cultivos celulares como substrato en los sistemas de producción de biológicos y procesos de aislamiento ofrece una buena alternativa comparado con el proceso realizado en huevos embrionados. El empleo de éste tipo de procedimientos reduce los riesgos de contaminación microbiológica y previene la presentación de reacciones alérgicas que podrían ser inducidas por la presencia, en el producto final, de componentes proteícos provenientes del huevo (20).

Es así como el aislamiento y cultivo de virus de influenza se constituye en uno de los principales retos en los laboratorios de diagnóstico y en los de la industria biofarmacéutica. Una alternativa la constituyen los cultivos primarios derivados de tejidos animales, dentro de los cuales se encuentran el cultivo primario de membranas coriónicas fetales humanas (21), el de cerebro de rata (22), el de células de cerebro de embriones de ratón (23), el cultivo primario de riñón y fibroblastos de embrión de pollo 
(24), el cultivo de células traqueales humanas (4) y el cultivo primario de células epiteliales respiratorias de cerdo (25), entre otros.

La principal ventaja de éste tipo de cultivos es su capacidad de ofrecer una mayor sensibilidad porque brinda todas las condiciones necesarias cuando se utilizan para el crecimiento in vitro de virus, principalmente a las cepas que infectan la misma especie de la cual fueron obtenidos. Los cultivos primarios per se presentan desventajas tales como el riesgo de contaminación con microorganismos adventicios, el alto costo de mantenimiento y suplementación del medio de cultivo. Así mismo, las tasas de recuperación de partículas virales pueden ser menos eficientes comparadas con las de la línea celular continua, además de la difícil estandarización de procedimientos para algunos de estos cultivos (26).

Una alternativa para contrarrestar las limitantes inherentes a los cultivos primarios, la constituyen las líneas celulares establecidas. Este tipo de cultivo se caracteriza por presentar una vida media infinita, facilitar la generación de clones, y adaptación a condiciones de crecimiento en un medio de cultivo en particular, además de ofrecer la posibilidad de documentar fácilmente su historial (8).

Específicamente en lo relacionado con el virus de influenza y en particular virus de influenza humana se han empleado para su cultivo líneas celulares tales como la Madin Darby Canine Kidney (MDCK) (6), las células embrionarias de retina humana (PER.C6) (27) y las células de riñón de mono verde Africano (VERO) (28), entre otras. En el caso de virus de influenza en cerdos por su parte se han empleado principalmente las líneas celulares MDCK (6), la línea celular epitelial intestinal de colon (CACO2) (29) y la línea celular de Riñón de Mono Verde Africano (VERO) (30).

En términos generales se puede decir que tradicionalmente, se han empleado los huevos embrionados de pollo y los cultivos de células Madin Darby Canine Kidney (MDCK) para el aislamiento y propagación del virus de influenza (31). Como se mencionó anteriormente en el caso de las células epiteliales de la cavidad alantoica éstas poseen únicamente receptores se ácido siálico con enlaces $\alpha-2.3$, mientras que las células MDCK poseen receptores con ambos tipos de enlaces $\alpha-2.3$ y a-2.6 (19), permitiendo el crecimiento de un mayor espectro de cepas del virus de influenza $A$. Actualmente se han publicado numerosos estudios que buscan determinar las características y sustratos óptimos para el crecimiento de virus de influenza a ser empleados en la producción de biológicos. En un estudio realizado por Gambaryan et al. (16), se observó que el crecimiento de virus de influenza porcina H1N1 clásico en células MDCK, con previo crecimiento en huevos embrionados presenta afinidad por receptor con enlace de tipo SAa-2.6, pero no con receptores tipo $S A \alpha-2.3$, encontrándose mayores tasa de replicación viral en células MDCK (receptores de tipo SAa-2.6) y escasas sustituciones en los aminoácidos que componen la HA de los virus empleados en el estudio.

Teniendo en cuenta las ventajas comparativas que ofrecen las líneas celulares con respecto al sistema tradicional de elaboración de vacunas contra el virus de influenza en huevos embrionados de pollo, las líneas celulares se han convertido, en un sistema alternativo viable y de elección para la producción de biológicos.

Por otra parte, se ha determinado que las moléculas de la HA de virus de influenza aislados en líneas celulares de mamíferos como la Madin Darby Canine Kidney (MDCK), Rhesus Monkey Kidney (LLC-MK-2), o células de riñón de mono verde africano (VERO) han sido antigénica y estructuralmente idénticas a las cepas encontradas en muestras de pacientes (17), razón por la cual, el uso de las líneas celulares ha sido evaluado para su empleo en el aislamiento y producción de vacunas contra el virus de influenza. Es necesario tener en cuenta varios factores en la selección de la línea celular destinada para la elaboración de vacunas, principalmente el tipo de biológico a desarrollar, bien sea si se trata de vacunas inactivadas (virus completo, subunidades, facciones virales) o vacunas a virus vivo atenuado como en el caso de los virus adaptados a frío, además de la capacidad de la línea celular para generar altos títulos de virus de influenza necesarios para la elaboración del biológico (32).

A continuación se presenta una revisión de los principales tipos de cultivo celular que han sido 
empleados en el crecimiento y/o aislamiento de virus de influenza y se discuten aspectos relacionados con los pros y los contras de su empleo como sustratos para la producción de vacunas.

\section{Líneas celulares empleadas con mayor frecuencia para el aislamiento del Virus de Influenza y su utilización en la producción de vacunas}

La línea celular MDCK (Madin Darby Canine Kidney) fue originalmente aislada en 1958 a partir del riñón de un perro adulto, aparentemente normal, de raza Cocker Spaniel, la cual fue subsecuentemente depositada en la American Type Culture Collection (ATCC) y se designó como CCL34 (registro de líneas celulares animales, 1965). A partir de 1975, el cultivo de células MDCK comenzó a ser ampliamente utilizado para el aislamiento de virus de influenza A y gracias a esto, es rutinariamente empleado en programas de vigilancia en salud pública, virología clínica y en laboratorios de investigación en todo el mundo por servir como un sustrato para el cultivo de virus de influenza mostrando una buena sensibilidad y permitiendo el crecimiento de un amplio rango de diferentes cepas del virus $(33,34)$.

En cuanto a su utilización en la producción comercial de vacunas, la línea celular MDCK ha sido empleada en la producción de vacunas inactivadas de influenza en Europa y para investigaciones clínicas en los Estados Unidos (33) Figura 1.

Una preocupación en la elaboración de vacunas derivadas de cultivos celulares es el potencial de formación de tumores por los residuos de la línea celular empleada, lo cual genera la necesidad de caracterizar los componentes celulares residuales que puedan quedar en el biológico, además de establecer la presencia de agentes adventicios y/o elementos con propiedades oncogénicas que representen un riesgo en el individuo receptor de la vacuna. Liu J. et al. (34), evaluaron el riesgo potencial de la línea celular MDCK de generar residuos en el sobrenadante del cultivo que puedan ocasionar la formación de tumores. Para esto emplearon un clon de las células MDCK (9B9-1E4) en dos modelos animales (ratones adultos y ratones recién nacidos). Encontrando que de

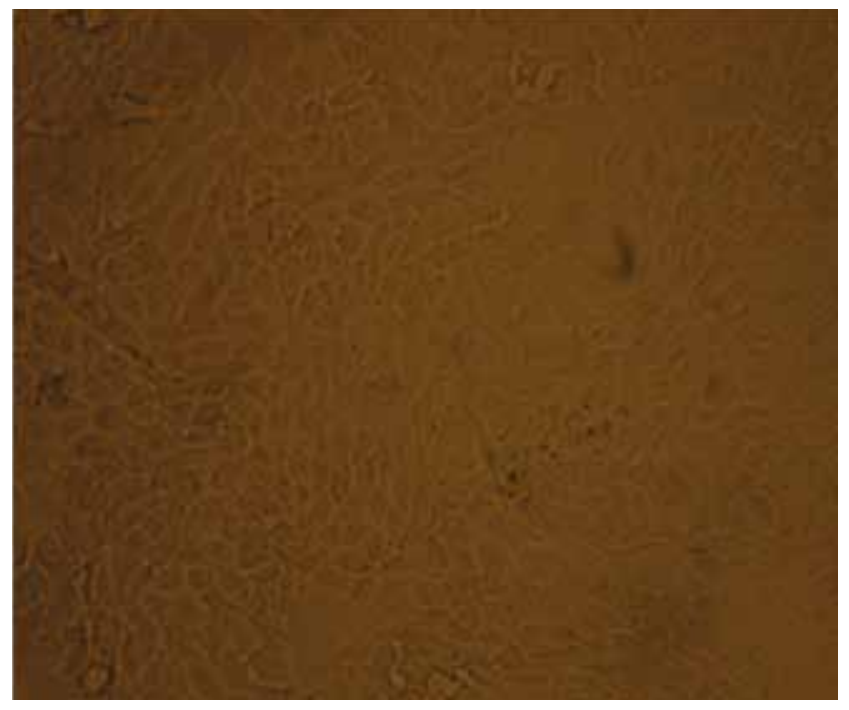

Figura 1. Línea Celular MDCK pase 16, aumento de 10X.

347 animales que fueron inyectados con varias dosis del lisado de células MDCK ( $>10^{7}$ células) solamente un animal desarrolló un sarcoma histiocítico, el cual no estuvo asociado a la aplicación del lisado de células, ya que no se encontró DNA de las células MDCK en el tumor, ni concordó con la tasa de eventos de presentación de tumores observada entre los animales inyectados y el control negativo (tratados con PBS). Este esudio así como otros reportes indican que las células MDCK no inducen la formación de tumores a bajas dosis ( $<10^{5}$ células) (35) presentando un bajo potencial oncogénico, con alta tasa de replicación del virus, características que hacen de este sustrato ideal para la producción de biológicos (34).

La Línea Celular Vero (Línea celular de Riñón de Mono Verde Africano) fue establecida en 1962 por Yasumara y Kawakita a partir del riñón de un mono verde africano normal. En la actualidad, la línea celular es distribuida por la American Type Culture Collection (ATCC) en pasaje 124 bajo la designación de ATCC CCL 81 (36). La Línea de células VERO es susceptible a un amplio rango de virus, siendo empleada para la fabricación de vacunas de poliomielitis y rabia en humanos (36), Así mismo, diferentes reportes han demostrado que este sustrato es apropiado para el aislamiento y la replicación productiva de virus de influenza $A$ y $B$ por los altos títulos infectivos que genera, manteniendo las características de la HA de los virus de influenza empleados en este sustrato (30). 
Una limitante en el uso de las células VERO para el crecimiento del virus de influenza se relaciona con el hecho de que éstas células inactivan rápidamente la tripsina exógena restringiendo así la replicación de los virus de influenza ya que la HA no puede ser clivada eficientemente (30). Sin embargo, dicha limitante puede ser superada mediante la adición repetida de tripsina al medio de cultivo lo cual mejora la replicación y multiplicación del virus de influenza tipo A (37).

En cuanto a las vacunas de influenza derivadas de células VERO, éstas han sido producidas y evaluadas por la generación de inmunogencidad y su producción ha sido escalada a niveles comerciales. Dichos biológicos inducen una respuesta humoral comparable a los biológicos producidos en huevos embrionados, siendo además, potentes estimulantes de la respuesta celular (38). En un estudio realizado por Bruhl et al., (39), compararon una vacuna trivalente de virus inactivado producida en células VERO con una vacuna producida en huevos embrionados, determinando la respuesta humoral y celular contra Influenza en ratones Balb/c, reportan que en todos los grupos de ratones inmunizados con los dos biológicos hubo respuesta de anticuerpos IgG de tipo IgG1 e IgG2a/2b. En cuanto a la respuesta de células T, IL-2 y INF-Y (Linfocitos T ayudadores o Th1) fueron producidos de forma significativa en los ratones que fueron inmunizados con la vacuna fabricada en células VERO; cabe destacar que la respuesta de tipo Th1 es la responsable de la estimulación de los linfocitos T citotóxicos requeridos para la eliminación de virus de influenza en el tejido pulmonar infectado (39).

Al comparar la eficiencia de las células MDCK y VERO en la replicación del virus de influenza Youil, R. et al., (28) determinaron que ambas líneas celulares son capaces de replicar el virus produciendo cargas virales máximas de $10-11 \log _{10}$ copias de genoma $/ \mathrm{ml}$. Sin embargo, las células MDCK generan cargas virales 2 a 3 veces más altas que las células VERO a las 24 y 48 horas postinfección; dichos resultados indican una mayor eficiencia en la replicación del virus en células MDCK frente a las células VERO, lo cual hace de las células MDCK un sustrato de elección para el aislamiento y crecimiento del virus de influenza.
La Línea Celular HEK-293 (células de riñón de embrión humano 293) Ha sido ampliamente empleada por la comunidad científica por más de 30 años como una plataforma eficiente para la producción a gran escala de proteínas recombinantes y vectores virales (20). Esta línea celular tiene como ventaja su fácil crecimiento en un cultivo en suspensión a altas densidades celulares $\left(10^{7}\right.$ células/ $\mathrm{ml}$ en tipo batch) y en medio libre de suero (20).

En el caso particular del uso de la línea celular HEK293 para la producción de vacunas contra el virus de Influenza, Le Ru A. et al. (20), evaluaron su uso como una alternativa eficiente para el escalamiento en la producción de virus de influenza empleando para éste fin las cepas A/PR/8/34 (H1N1), A/WS/33 (H1N1), A/Aichi/2/68 (H3N2), A/Hong Kong/8/68 (H3N2) y la $\mathrm{B} /$ Lee/40. Dentro de los parámetros evaluados se determinó la presencia de receptores $\alpha-2.3$ y $\alpha-2.6$ en la superficie de las células HEK-293, realizando simultáneamente la detección de dichos receptores en células MDCK. Para evaluar la propagación del virus de influenza en células HEK-293 se empleó la técnica de inmunofluorescencia, a través de la cual, en el caso de la cepa A/PR/8/34 (H1N1) se determinó replicación del virus a las 24 horas post-infección. El número de partículas infectivas aumentó a las $48 \mathrm{hpi}$, mientras la viabilidad celular permaneció alta $(>80 \%)$, observándose efecto citopático característico de células infectadas por virus de influenza a las 72 y 96 hpi. Los autores señalan que las células de la línea HEK293 presentan ventajas tales como un crecimiento rápido en suspensión en un medio de cultivo libre de suero, son capaces de producir altos títulos de virus infecciosos de influenza para los diferentes subtipos $(\mathrm{A} / \mathrm{H} 1, \mathrm{~A} / \mathrm{H} 3$ y $\mathrm{B})$ sin requerir adaptaciones previas, generando partículas virales con las características de los virus de influenza (20).

Sin embargo, al comparar la eficiencia de repliación de virus de influenza en la línea celular HEK-293 frente a la línea MDCK, se encontró que las células HEK-293 presentan un rendimiento más bajo principalmente en los primeros pasajes del virus en el cultivo celular.

La Línea Celular CACO-2 (adenocarcinoma de colon humano) tiene como característica distintiva que no requiere de la adición de tripsina al medio de 
cultivo debido a que contiene las proteasas necesarias para el clivaje de la HA, facilitando así el ingreso del virus de influenza a la célula y la observación del efecto citopático $(40,29)$. La línea celular de epitelio intestinal de colon (CACO-2) ha mostrado mayor eficiencia en el aislamiento de virus de influenza del tipo A H3N2 y H1N1 en muestras clínicas provenientes de humanos comparado con la línea MDCK o los huevos embrionados (40). Las células Caco-2 contienen receptores de ácido siálico de tipo a-2.3 (preferencialmente para virus de influenza aviar) y $\alpha-2.6$ (preferencialmente para virus de influenza humana $(31,40)$. Así mismo Jahangir et al. (41) reporta que las células CACO-2 son permisivas al virus de influenza aviar de baja patogenicidad, indicando que dicha sensibilidad es similar a la encontrada en huevos embrionados.

Con el fin de determinar el comportamiento de diferentes substratos para el aislamiento de virus de influenza en cerdos, Chiapponi, C. et al. (29), realizaron un estudio en el que se evaluó la eficiencia de las líneas celulares CACO-2, MDCK y la inoculación en huevos embrionados para el aislamiento de virus de influenza porcina A H1N1, H1N2 y H3N2 a partir de muestras clínicas. Se obtuvieron resultados que variaron de acuerdo a los diferentes subtipos en relación con los sustratos evaluados. Es así como el $100 \%$ de los virus de los subtipos H1N1 y H1N2 fueron aislados en células $\mathrm{CACO}-2$, mientras que en el mismo sustrato solo el $50 \%$ de los virus del subtipo $\mathrm{H} 3 \mathrm{~N} 2$ fue aislado. Esto contrasta con los resultados encontrados en la inoculación en huevos embrionados, donde se aisló con mayor frecuencia virus del subtipo $\mathrm{H} 3 \mathrm{~N} 2$, mientras que solo el $44 \%$ del virus $\mathrm{H} 1 \mathrm{~N} 1$ y el 11\% del virus $\mathrm{H} 1 \mathrm{~N} 2$ fueron aislados en este sustrato. Por su parte, los resultados de la inoculación de los mismo subtipos en células MDCK, mostraron que el porcentaje de aislamientos positivos fue del $56 \%$ para el subtipo $\mathrm{H} 1 \mathrm{~N} 1$, del $3.5 \%$ para el subtipo H1N2 y del 38\% para el subtipo H3N2. Los resultados obtenidos en ése estudio, sugieren que existe una fuerte asociación entre la cepa del virus y el tropismo celular. Aunque el sustrato que presentó mayor eficiencia en el aislamiento viral para los subtipos $\mathrm{H} 1 \mathrm{~N} 1$ y H1N2 fue la línea celular CACO2, comparada con las células MDCK y los huevos embrionados. Sin embargo, la detección del subtipo H3N2 fue mucho más alta en huevos embrionados. Con base en lo anterior se sugiere que para lograr detectar los tres subtipos del virus involucrados en la presentación de influenza porcina, es necesario emplear simultáneamente los dos sustratos (células CACO-2 y huevos embrionados) $(29,40)$.

\section{Otras líneas celulares}

Otros tipos de líneas celulares tales como las líneas MRC-5, WI-38, FrhL, se han empleado igualmente para la replicación de virus de influenza con el fin de utilizarlos en la fabricación de vacunas. La línea MRC-5 (Medical Research Council 5) es de origen de fibroblastos de pulmón humano provenientes de un feto masculino de 14 semanas; en la ATCC tiene registro número CCL-171. Esta línea celular fue preparada y desarrollada por J. P. Jacobs en 1966. Es empleada principalmente para la replicación y elaboración de vacunas de influenza humana debido a que estas células presentan receptores de tipo SAa2-6, sin embargo, presentan como desventaja su baja sensibilidad $(57,1 \%)$ a virus de influenza humana cuando se compara con las células MDCK (100\% de sensibilidad), lo cual hace que su uso sea de baja elección para la replicación de dicho virus $(35,41)$. La línea WI-38 (Winstar Institute 38) es de origen de fibroblastos diploides de pulmón humano, derivados de un feto femenino. Fue preparada y desarrollada por Leonard Hayflick en 1964, tiene registro ATCC número CCL-75. Esta línea celular ha sido usada para la preparación de la vacuna RA 27/3 contra la rubéola. En cuanto al virus de influenza se ha demostrado que genera altas tasas de replicación viral (21), sin embargo una vida media limitada es su principal desventaja. La línea FrhL con registro ATCC-CCL160, es de origen de fibroblastos de pulmón de un feto de mono hembra Rhesus. Esta es una línea celular diploide que ha sido utilizada para la replicación de virus de influenza porque produce títulos altos de virus y ha sido recomendada para la producción de vacunas comerciales. Al igual que la anterior, esta línea celular presenta como limitante una vida media limitada ya que al estar compuesta por células diploides limita su utilización como sustrato para la 
Tabla 1. Líneas celulares de origen humano susceptibles a Virus de Influenza A

\begin{tabular}{|c|c|c|c|}
\hline Línea Celular & Origen/Humano & Tipo de Línea & ID ATCC \\
\hline HEp-2 & Tracto respiratorio superior & Cáncer Laríngeo & CCL-23 $3^{\mathrm{TM}}$ \\
\hline A549 & Tracto respiratorio inferior & Adenocarcinoma de pulmón & CCL-185 \\
\hline Caco-2 & Tracto Gastrointestinal & Adenocarcinoma Colorectal & HTB-37 $7^{\mathrm{TM}}$ \\
\hline HeLa & Tracto genitourinario & Adeocarcinoma Cervical & CCL-2 $2^{\mathrm{TM}}$ \\
\hline NT2 & Neuromuscular & $\begin{array}{l}\text { Teratocarcinoma de células } \\
\text { neuronales }\end{array}$ & CRL- $1973^{\mathrm{TM}}$ \\
\hline THP-1 & Células Inmunes & $\begin{array}{l}\text { Monocitos de sangre periférica de } \\
\text { leucemia monocitica aguda }\end{array}$ & TIB-202 ${ }^{\mathrm{TM}}$ \\
\hline U937 & Células Inmunes & Monocitos de linfoma histiocitico & CRL- $1973^{\mathrm{TM}}$ \\
\hline H9 & Células Inmunes & $\begin{array}{l}\text { Linfocitos } \mathrm{T} \text { derivados del } \\
\text { Síndrome de Sezary }\end{array}$ & HTB- $176^{\mathrm{TM}}$ \\
\hline Raji & Células Inmunes & $\begin{array}{l}\text { Linfocitos B del linfoma de } \\
\text { Burkitts }\end{array}$ & CCL-86 ${ }^{\mathrm{TM}}$ \\
\hline
\end{tabular}

Modificado de IWS Li et al., 2009

producción de biológicos por su manejo dispendioso y bajo rendimiento a gran escala (6).

Al comparar la eficiencia de las líneas celulares MRC-5, WI-38, FRhL, VERO y MDCK como sustratos para la producción de vacunas vivas atenuadas de influenza Liu, J. et al., (34) encontraron que las células MRC-5, WI-38 y FRhL no produjeron títulos suficientemente altos de varios subtipos de virus los cuales son necesarios para la producción del biológico. En el caso de las células VERO se considera que éstas producen títulos altos para un número limitado de dichos subtipos y requieren de altas cantidades de suero fetal bovino, lo cual limita el crecimiento de las cepas vacunales, haciendo de esta línea celular un sustrato de baja elección para la producción de vacunas vivas atenuadas de influenza. En contraste, las células MDCK son capaces de producir títulos altos de cepas vacunales vivas atenuadas para un amplio rango de subtipos y variantes de cepas de virus de influenza estacional $\mathrm{A} / \mathrm{H} 1, \mathrm{~A} / \mathrm{H} 3 \mathrm{y}$ de influenza B $(16,18)$.

\section{Diferencias en la replicación del Virus de Influenza a en líneas celulares susceptibles}

A través del tiempo, se han estudiado diversas líneas celulares originadas de diferentes órganos y especies para poder establecer la susceptibilidad de dichos sustratos a diferentes virus de influenza. En la Tabla 1 se presentan algunas líneas celulares susceptibles a virus de influenza. Dentro de los sustratos originados de humanos, se encuentra una amplia variedad de cultivos celulares que han respondido de forma diferente en cuanto a la tasa de replicación viral, Tabla 1 .

En cuanto a líneas celulares de origen animal que son susceptibles al virus de influenza se encuentra un número más limitado de sustratos provenientes de diversos orígenes y especies tales como los primates no humanos, cerdos y caninos, Tabla 2.

Con el fin de comparar la susceptibilidad al virus de influenza en diferentes líneas celulares de origen humano y animal, IWS Li et al., (32) emplearon los virus $\mathrm{A} / \mathrm{HK} / 415742 / 09$ (H1N1) de origen porcino, $\mathrm{A} /$

Tabla2. Líneas Celulares de Origen Animal Susceptibles a Virus de Influenza A

\begin{tabular}{l|l|l|l}
\multicolumn{1}{c|}{ Línea Celular } & \multicolumn{1}{c|}{ Origen/Animal } & \multicolumn{1}{c|}{ Tipo de Línea } & \multicolumn{1}{c}{ ID ATCC } \\
MDCK & $\begin{array}{l}\text { Riñón de canino de raza Cocker } \\
\text { Spaniel }\end{array}$ & Madin-Darby Canine Kidney & CCL-34 \\
LLC-MK2 & Riñón de mono & Riñón de mono Rhesus & CCL-7 \\
BSC-1 & Epitelio Renal & $\begin{array}{l}\text { Epitelio renal de mono verde } \\
\text { Africano }\end{array}$ & CCL-26 \\
PK-15 & Riñón de cerdo & Riñón de porcino & CCL-33 \\
\hline
\end{tabular}

Modificado de IWS Li et al., 2009 
$\mathrm{HK} / 403946 / 09$ (H1N1) estacional humano y H5N1 A/Vietnam/1194/04 de origen aviar para determinar y comparar su replicación en diferentes substratos.

En el caso de la cepa H5N1 se encontró que dicho virus fue capaz de replicarse en todas las líneas celulares, a excepción de las células Hep-2. Las cepas H1N1 de origen humano y H1N1 de origen porcino fueron capaces de replicarse en líneas celulares derivadas del tracto respiratorio inferior, tracto gastrointestinal, hígado, riñón y músculo.

Con respecto a las líneas celulares de origen animal, la replicación fue detectada en todas las líneas celulares (mono, perro, cerdo). La cepa H5N1 mostró mayor eficiencia de replicación comparada con los virus $\mathrm{H} 1 \mathrm{~N} 1$ de origen humano y porcino. En cuanto a susceptibilidad de las líneas celulares de origen animal se determinó que los sustratos que son más sensibles a los tres subtipos de virus de influenza son la línea celular MDCK, BSC-1 y PK-15 (32).

De la misma forma, se ha podido determinar que los virus de influenza de origen humano, porcino y aviar tienen una amplia variedad de líneas celulares para su replicación, pero se ha encontrado que pocos sustratos entre los cuales están los derivados del tracto respiratorio inferior, algunas líneas del tracto gastrointestinal y en el caso de las líneas de origen animal la línea celular MDCK, son capaces de hacerlo eficientemente. $(42,32)$.

\section{Cultivos en suspensión para la producción de virus de Influenza}

La plataforma de producción de vacunas basadas en cultivos celulares, permite la extensión a gran escala siempre y cuando las células se manejen en suspensión. Un sistema similar de producción es necesario en el caso de aparición de epidemias o pandemias. Como ejemplo están las vacunas producidas en cultivos celulares de virus de rabia, poliovirus y rotavirus fabricados en células VERO (43).

Así mismo, se ha determinado que el uso de células en suspensión simplifica los procesos de producción de vacunas en forma escalable, debido a que las superficies de crecimiento de las células como los microportadores no requieren anclaje y tampoco de procesos como desprendimiento de las células entre cada pasaje celular. Una ventaja adicional del uso de cultivos en suspensión es que permite el uso de medios químicos definidos, los cuales no requieren suplementación con suero fetal bovino lo cual elimina riesgos potenciales del uso de dicho suero como son la variación entre lotes y el riesgo potencial de contaminación con mycoplasma, virus o priones (44); reduciendo además los costos de producción.

Como se ha mencionado previamente, las células MDCK presentan características de sustrato ideal para la replicación de virus de influenza, pero su rápida expansión en cultivo es difícil debido a su crecimiento dependiente de anclaje (43). Chu et al., (43) generaron células MDCK que fueran capaces de crecer en suspensión mediante la transfección del gen humano sialiltransferasa (siat7e) que disminuye la adhesión celular. Para determinar la susceptibilidad de esta nueva línea celular (MDCK-siat7e) y la producción escalable de virus, se emplearon en el estudio 4 virus vacunales (A/California/07/2009 X-179A H1N1, A/Brisbane/59/2007 IVR-148 H1N1, A/Uruguay/716/2007 X-175C H3N2, y B/ Brisbane/60/2008). Se determinó que la línea celular MDCK-siat7e fue capaz de replicar las cuatro cepas, generando títulos hemaglutinantes de 1:512; un inconveniente es que la progenie de virus colectada después de pasajes seriales exhibieron mutaciones mínimas en el gen que codifica para la proteína HA. Sin embargo, este proceso ofrece perspectivas para la implementación de cultivos en suspensión con células MDCK para el crecimiento de virus de influenza a ser utilizados en la elaboración de vacunas (44-49).

Como desventajas del crecimiento de células MDCK en suspensión, se ha determinado que estas células pueden formar quistes multicelulares que generan polarización de las membranas celulares disminuyendo el porcentaje de replicación celular de 1-4\%. Además, presentan disminución en la agregación celular seguido de una baja viabilidad que va a inducir a la apoptosis celular (44). Se determinó igualmente que las células MDCK- siat7e presentan escape de aniones cuando crecen en suspensión sugiriendo que estas células puedan volverse tumorogénicas como resultado de la modificación de la actividad de la enzima sialiltransferasa (50-53).

Aunque existe el riesgo de tumorogenicidad y a pesar de las desventajas que pueden presentar 
los cultivos en suspensión, se están llevando a cabo diversos estudios que buscan superar estos inconvenientes, ya que para lograr la producción de biológicos a partir de cultivos celulares a nivel industrial se hace necesario establecer líneas celulares en suspensión que facilitan y agilizan el escalamiento de los procesos en la elaboración de vacunas que optimicen tiempo, costos y la rápida reacción frente a la presentación de epidemias o pandemias (54-58).

\section{Conclusiones}

El aislamiento y cultivo de virus de influenza es uno de los principales retos en los laboratorios de diagnóstico y en la industria biofarmacéutica, ya que la biología propia del virus exige que el sustrato presente una serie de parámetros que ofrezcan al virus las condiciones ideales para su replicación in vitro. Estas condiciones están asociadas con la preferencia por el receptor celular, que los virus de influenza A requieren para inducir infección.

A pesar de que la inoculación en huevos embrionados de pollo es el sistema biológico de elección para el aislamiento y crecimiento de virus de influenza, este sustrato presenta como principal inconveniente una difícil disponibilidad oportuna en cantidades suficientes para la producción de virus que va a ser utilizado en la producción de vacunas, particularmente en el caso de epidemias o pandemias, además del riesgo de generar variaciones en la secuencia de la hemaglutinina (HA), debido a un proceso de adaptación del virus al crecimiento en éste tipo de substrato. Debido a las limitantes conocidas acerca del uso de los huevos embrionados para la fabricación de vacunas contra influenza, se han evaluado diversas líneas celulares que ofrecen ventajas sobre los huevos embrionados, entre las cuales se destacan la facilidad de emplear células completamente caracterizadas y estandarizadas, mayor capacidad y rapidez de producción de biológicos en el caso de la aparición de una nueva cepa de virus (pandemia) y menor riesgo de cambio en las propiedades de unión al receptor de la HA.

La generación de vacunas a partir de cultivos celulares es una excelente alternativa que nace de la necesidad de producir en corto tiempo biológicos seguros que no generen reacciones indeseadas en la población y principalmente que controlen la presentación y diseminación de la enfermedad a nivel mundial, ya que la población humana y animal se han visto seriamente afectados por el comportamiento cambiante e impredecible del virus de influenza; de esta forma, los cultivos celulares abren un sinnúmero de posibilidades para la industria dedicada a la generación de biológicos.

\section{Referencias}

1. Acosta O, Guerrero CA, Cortés JA. ASPECTOS BÁSICOS, CLÍNICOS Y EPIDEMIOLÓGICOS DE LA INFLUENZA. Rev.Fac.Med 2009 Vol. 57 No. 2

2. Flint, S.J. Principles of Virology: molecular biology, pathogenesis and control of animal viruses. $2^{\text {nd }}$ ed. Washington, USA. 2004. p. 918.

3. Gramer M. An update on swine influenza ecology and diagnostics. American Association of Swine Veterinarians, 2008.

4. Reemers S, Koerkamp M, Holstege F, Eden W, Vervelde L. Cellular host transcriptional responses to influenza A virus in chicken tracheal organ cultures differ from responses in in vivo infected trachea. Veterinary Immunology and Immunopathology 132 (2009) 91-100

5. Reeth VK, Vleeschauwer A, Kyriakis C, Pensaert M. Influenza in Birds, Pigs and Humans: Old Theories versus Current Viewpoints. Proceedings of the $19^{\text {th }}$ IPVS congress, Copenhagen, Denmark, 2006. Volume 1.

6. Voeten JTM, Brands R, Palache AM, van Scharrenburg GJM, Rimmelzwaan GF, Osterhaus ADME, et al. Characterization of high-growth reassortant influenza A viruses generated in MDCK cells cultured in serum-free medium. Vaccine 1999;17:1942-50

7. Couch RB. Seasonal inactivated influenza virus vaccines. Vaccine $26 \mathrm{~s}$ (2008) D5 - D9

8. Tree JA, Richardson C, Fooks AR, Clegg JC, Looby D. Comparison of large-scale mammalian cell culture systems with egg culture for the production of influenza virus A vaccine strains. Vaccine 19 (2001) 3444-3450

9. Robertson JS, Bootman JS, Newman R, et al. Structural changes in the haemagglutinin which accompany egg adaptation of an influenza A(H1N1) virus. Virology 1987; 160:31-7.

10. Chu VC, Whittaker GR. Influenza virus entry and infection require host cell N-linked glycoprotein. Proc. Natl. Acad. Sci. 101 (52), 2004; 18153-18158.

11. Rogers GN \& D'Souza BL. Receptor binding properties of human and animal H1 influenza virus isolates. Virology 173, 1989; 317-322.

12. Rogers GN \& Paulson JC. Receptor determinants of human and animal influenza virus isolates: differences in receptor specificity of the $\mathrm{H} 3$ hemagglutinin based on species of origin. Virology 127, 1983; 361-373.

13. Ito T, Couceiro JN, Kelm S, Baum LG, Krauss S, Castrucci MR. Molecular basis for the generation in pigs of influenza A viruses with pandemic potential. J Virology 72. 1998; 7367-7373.

14. Lee CW, Jung K, Jadhao SJ, Suarez DL. Evaluation of chicken-origin (DF-1) and quail-origin (QT-6) fibroblast cell lines for replication of avian influenza viruses. J. Virol. Methods 153, 2008; 22-28.

15. Steinhauer DA. Role of hemagglutinin cleavage for the pathogenicity of influenza virus. Virology 258, 1999; 1-20.

16. Gambaryan AS, Karasin AI, Tuzikov AB, Chinarev AA, Pazynina GV, Bovin NV, et al. Receptor-binding properties of swine influenza viruses isolated and propagated in MDCK cells. Virus Res. 2005; 114 (1-2), 15-22.

17. Romanova J, Katinger D, Ferko B, Voglauer R, Mochalova L, Bovin N, et al. Distinct host range of influenza $\mathrm{H} 3 \mathrm{~N} 2$ virus isolates in Vero and MDCK cells is determined by cell specific glycosylation pattern. Virology 307 (2003) 90-97

18. Gambaryan AS, Marinina VP, Tuzikov AB, Bovin NV, Rudneva IA, Sinitsyn BV, et al. Effects of host-dependent glycosylation of hemagglutinin 
on receptor-binding properties on $\mathrm{H} 1 \mathrm{~N} 1$ human influenza A virus grown in MDCK cells and in embryonated eggs. Virology 247. 1998; 170-177

19. Ito T, Suzuki Y, Takada A, Kawamoto A, Otsuki K, Masuda H, et al Differences in sialic acid-galactose linkages in the chicken egg amnion and allantois influence human influenza virus receptor specificity and variant selection. J Virology 71, 1997; 3357-3362.

20. Le Ru A, Jacob D, Transfiguracion J, Ansorge S, Henry O, Kamen AA. Scalable production of influenza virus in HEK-293 cells for efficient vaccine Manufacturing. Vaccine 28 (2010) 3661-3671

21. Uchide N, Suzuki A, Ohyama K, Bessho T, Toyoda H. Secretion of Bioactive Interleukin- 6 and Tumor Necrosis Factor- $\mathbb{D}$ Proteins from Primary Cultured Human Fetal Membrane Chorion Cells Infected with Influenza Virus . Placenta, Volume 27, Issues 6-7, June-July 2006, Pages 678-690

22. Takahashi M, Yamada T, Nakanishis K, Fujitas K, Nakajima’i K, Nobusawa E, et al. Influenza A Virus Infection of Primary Cultured Cells From Rat Fetal Brain. Parkingsonism \& Related Disorders. Vol. 3, No. 2, pp $97-102,1997$

23. Bradshaw GL, Schwartz CD, Schlesinger RW. Replication of H1N1 influenza viruses in cultured mouse embryo brain cells: Virus strain and cell differentiation affect synthesis of proteins encoded in RNA segments 7 and 8 and efficiency of mRNA splicing. Virology, Volume 176, Issue 2, June 1990, Pages 390-402

24. Tannock GA, Bryce DA, Paul JA. Evaluation of chicken kidney and chicken embryo kidney cultures for the large-scale growth of attenuated influenza virus master strain A/Ann/Arbor/6/60-ca. Vaccine, Volume 3, Issue 4, September 1985, Pages 333-339

25. Busch MG, Bateman AC, Landolt GA, Karasin AI, Brockman-Schneider RA, Gern JE, et al. Identification of amino acids in the $\mathrm{HA}$ of $\mathrm{H} 3$ influenza viruses that determine infectivity levels in primary swine respiratory epithelial cells. Virus Research, Volume 133, Issue 2, May 2008, Pages 269-279

26. Initiative for Vaccine Research World Health Organization. Use of Cell Lines for the Production of Influenza Virus Vaccines: An Appraisal of Technical, manufacturing, and Regulatory Considerations Geneva, Switzerland, 10 April 2007

27. Pau MG, Ophorst C, Koldijk MH, Schouten G, Mehtali M, Uytdehaag F. The human cell line PER.C6 provides a new manufacturing system for the production of influenza vaccines. Vaccine 2001; 19:2716-21.

28. Youil R, Su Q, Toner TJ, Szymkowiak C, Kwan WS, Rubin B, et al. Comparative study of influenza virus replication in Vero and MDCK cell lines. J Virol Methods 2004; 120:23-31.

29. Chiapponi C, Zanni I, Garbarino C, Barigazzi G, Foni E. Comparison of the usefulness of the CACO-2 cell line with standard substrates for isolation of swine influenza A viruses. Journal of Virological Methods 163 (2010) 162-165

30. Govorkova EA, Murk G, Meignier B, De Taisne C. and Webster RG. African Green Monkey Kidney (Vero) cells provide an alternative host cell system for Influenza A and B virus. J. Viral. 1996, 70, 5519-5524.

31. Takemae N, Ruttanapumma R, Parchariyanon S, Yoneyama S, Hayashi T, Hiramatsu $\mathrm{H}$, et al. Animal cell culture in pharmaceutical biotechnology: research and perspectives. Revista Mexicana de Ciencias Farmaceúticas. Volumen 40, Número 4, Octubre - Diciembre 2009

32. I.W.S. Li, K.H. Chan, K.W.K. To, S.S.Y. Wong, P.L. Ho, S.K.P. Lau, et al. Differential susceptibility of different cell lines to swine-origin influenza A H1N1, seasonal human influenza A H1N1, and avian influenza A H5N1 viruses. Journal of Clinical Virology 46 (2009) 325-330

33. Clavijo A, Tresnan DB, Jolie R, Zhou EM. Comparison of embryonated chicken eggs with MDCK cell culture for the isolation of swine influenza virus. The Canadian Journal of Veterinary Research. 2002; 66:117.121

34. Liu J, Mani S, Schwartz R, Richman L, Tabor DE. Cloning and assessment of tumorigenicity and oncogenicity of a Madin-Darby canine kidney (MDCK) cell line for influenza vaccine production. Vaccine 28 (2010) 1285-1293

35. Medema JK, Meijer J, Kersten AJ, Horton R. Safety assessment of Madin Darby canine kidney cells as vaccine substrate. Dev Biol (Basel) 2006; 123:243-50[discussion 65-6].

36. Kistner O, Barrett PN, Mundt W, Reiter M, Schober-Bendixen S, and Darner F. Development of a mammalian cell (Vero) derived candidate influenza virus vaccine. Vaccine 1998 Volume 16 Number 9/1 0

37. Ozaki H, Govorkova EA, Li C, Xiong X, Webster RG, and Webby RJ. Generation of High-Yielding Influenza A Viruses in African Green
Monkey Kidney (Vero) Cells by Reverse Genetics. Journal of Virology, Feb. 2004, p. 1851-1857

38. Oxford JS, Corcoran T, Knott R, et al. Serological studies with influenza $\mathrm{A}(\mathrm{H} 1 \mathrm{~N} 1)$ viruses cultivated in eggs or in a canine kidney cell line (MDCK). Bull World Health Organ 1987; 65:181-7.

39. Bruhl P, Kerschbaum A, Kistner O, Barrett N, Dorner F, Gerencer M. Humoral and cell-mediated immunity to Vero cell-derived influenza vaccine. Vaccine 19 (2001) 1149-1158

40. Zhirnov OP and Klenk HD. Human influenza A viruses are proteolytically acti- vated and do not induce apoptosis in Caco- 2 cells. Virology 313, 2003; 198-212.

41. Arbeláez G, Calderón D, Rincón M, Lora A, Mercado M. Implementación de dos metodologías diagnósticas para la determinación del virus de influenza porcina. Universitas Scientiarum, Revista de la Facultad de Ciencias Vol. $13 \mathrm{~N}^{\circ}$ 1, 65-74. Enero-Junio 2008

42. García-Sastre A, Durbin RK, Zheng H, Palese P, Gertner R, Levy DE, et al. The role of interferon in influenza virus tissue tropism. J Virol $1998 ; 72: 8550-8$.

43. Chu C, Lugovtsev V, Lewis A, Betenbaugh M, Shiloach J. Production and antigenic properties of influenza virus from suspension MDCK-siat7e cells in a bench-scale bioreactor. Vaccine 28 (2010) 7193-7201.

44. Wielink R. van, Kant-Eenbergen HCM, Harmsen MM, Martens DE, Wijffels RH, Coco-Martin JM. Adaptation of a Madin-Darby canine kidney cell line to suspension growth in serum-free media and comparison of its ability to produce avian influenza virus to Vero and BHK21 cell lines. Journal of Virological Methods 171 (2011) 53-60

45. Bardiya N, Bae JH. Influenza vaccines: recent advances in production technologies. Appl Microbiol Biotechnol 2005; 67: 299-305.

46. Belsey M, Evans D, Pavlou A, Savopoulos J. Growth drivers and resistors of the influenza market: The importance of cell culture flu. J Commercial Biotechnol 2005;12 (2):150-5.

47. Groth N, Montomoli E, Gentile C, Manini I, Bugarini R, Podda A. Safety, tolerability and immunogenicity of a mammalian cell-culturederived influenza vaccine: A sequential Phase I and Phase II clinical trial. Vaccine 27 (2009) 786-791

48. Katz J M, Naeve CW \& Webster RG. Host cell-mediated variation in H3N2 influenza viruses. Virology 156, 1987; 386-395.

49. Liu Jonathan, Shi X, Schwartz R, Kemble G. Use of MDCK cells for production of live attenuated influenza vaccine. Vaccine 27 (2009) 6460-6463

50. Maines TR, Jayaraman A, Belser JA, Wadford DA, Pappas C, Zeng H, et al. Transmission and pathogenesis of swine-origin 2009 A (H1N1) influenza viruses in ferrets and mice. Science 2009; 325:484-7.

51. Mochalova L, Gambaryan A, Romanova J, Tuzikov A, Chinarev A, Katinger D, et al. Receptor-binding properties of modern human influenza viruses primarily isolated in Vero and MDCK cells and chicken embryonated eggs. Virology 313 (2003) 473-480

52. Naffakh N, Van der Wef S. April 2009: an outbreak of swine-origin influenza $\mathrm{A}(\mathrm{H} 1 \mathrm{~N} 1)$ virus with evidence for human to human transmission. Microbes and Infection 11 (2009) 725-728.

53. Nicholson KG, Wood JM, Zambon M. Influenza. The Lancet. Vol 362 November 22, 2003

54. Robertson JS, Cook P, Attwell AM, et al. Replicative advantage in tissue culture of egg-adapted influenza virus over tissue-culture derived virus: implications for vaccine manufacture. Vaccine 1995; 13:1583-8.

55. Saito T. Alterations in receptor-binding properties of swine influenza viruses of the $\mathrm{H} 1$ subtype after isolation in embryonated chicken eggs. Journal of General Virology (2010), 91, 938-948

56. Takemae N, Ruttanapumma R, Parchariyanon S, Yoneyama S, Hayashi $\mathrm{T}$, Hiramatsu $\mathrm{H}$, et al. Alterations in receptor-binding properties of swine influenza viruses of the $\mathrm{H} 1$ subtype after isolation in embryonated chicken eggs. Journal of General Virology (2010), 91, 938-948

57. Yewdell $\mathrm{J}$ and García-Sastre A. Influenza virus still surprises. Current Opinion in Microbiology 2002, 5:414-418

58. Zhirnov OP, Vorobjeva IV, Saphonova OA, Malyshev NA, Ovcharenko AV, Klenk HD. Specific biochemical features of replication of clinical influenza viruses in human intestinal cell culture. Biochemistry (Mosc.) 72, 2007; 398-408. 